\title{
Comparative study of Aceclofenac with Etoricoxib on degree of analgesia and assessment of incidence of hypertension and peptic ulcer in rheumatoid arthritis patients
}

\author{
Ashalatha Muppur, Anitha.N \\ (Assistant professor,dept of pharmacology,s.v.medical college,drntr university of health sciences,india) \\ (Assistant professor, dept of pharmacology,s.v.medical college,drntr university of health sciences, india)
}

\begin{abstract}
:
Background: Rheumatoid Arthritis Is A Chronic Systemic Inflammatory Disease Of Unknown Cause,Chiefly Affecting Synovial Membranes Of Multiple Joints. First Line Drugs Used For Treatment Of This Condition Are Nonsteroidal Anti Inflammatorydrugs,Second Line Drugs Are Low Dose Glucocorticoids And The Last Resort For Rheumatoid Arthritis Is Disease Modifying Antirheumatic Drugs.

Aim: In This Study Efficacy Of Aceclofenac And Etoricoxib, Which Are Both Nsaids, Were Compared.Degree Of Analgesia Is Assessed Through Visual Analogue Scale(Vas)And Measuring Number Of Tender Joints In The Body.Finally This Study Assess The Incidence Of Hypertension And Peptic Ulcer In Rheumatoid Arthritis Patients Taking These Drugs.
\end{abstract}

Material And Methods: This Was A Randomized,Parallel Group,Open Label,Comparative Controlled Study.Patients Were Randomly Assigned To Groupa $(N=30)$ And Groupb $(N=30)$, Who Received

Aceclofenac(100mg)And Etoricoxib(90mg)Respectively.

Result: Both Aceclofenac And Etoricoxib Showed

Decrease In Vas And Number Of Tender Joints After24 Weeks, $(P<0.05)$ Establishing Them As Good Analgesics.Decrease In Vas And Number Of Tender Joints Was More With Aceclofenac Than

Etoricoxib(P<0.05).Etoricoxib Caused Mild Increase In Systolic And Diastolic Blood Pressure $(P<0.05)$ Which Was Statistically Significant.In One Person Out Of 30 Who Were On Aceclofenac Developed Peptic Ulcer $(P>0.05)$ Which Was Statistically Insignificant.

Conclusion: Aceclofenac Is A Better Choice Than Etoricoxib For Analgesia In Rheumatoid Arthritis Patients. Keywords: Aceclofenac,Etoricoxib,Rheumatoid Arthritis, Visual Analogue Scale,Blood Pressure

\section{Introduction}

Rheumatoid arthritis is an autoimmune disease in which there is joint inflammation and destruction of articular cartilage. The prevalence in general population is $1-2 \%$,female patients outnumbering males (3:1).The usual age of onset is fourth and fifth decades,with 80\% developing at ages 37 to 57 years.One of the major genetic factors in the etiology of rheumatoid arthritis is the class2 major histocompatibility complex (MHC) gene product $\mathrm{HLA} \mathrm{DR}$. The various gene products of MHC associated with rheumatoid arthritis include HLA $\mathrm{DR}_{4} / \mathrm{DW}_{4}{ }^{[1]}, \mathrm{HLA} \mathrm{DR}_{4} / \mathrm{DW}_{14}, \mathrm{HLA}, \mathrm{DR}_{4} / \mathrm{DW}_{15}, \mathrm{HLA} \mathrm{DR}_{4} / \mathrm{DW}_{16}$ and HLA $\mathrm{DR}_{1}$. The cause ${ }^{[2]}$ of rheumatoid arthritis remains unknown.

A number of possible causative agents have been suggested,including mycloplasma,epstien barr virus,cytomegalo virus,parvo virus and rubella virus but convincing evidence is lacking. The pathogenesis ${ }^{[3,4]}$ is microvascular injury and increase in number of synovial lining cells ${ }^{[5]}$.This is the initial lesion in rheumatoid arthritis.As the process continues synovium becomes edematous and protrudes into the joint cavity as villous projection.The inflammed synovium is referred to as pannus.Hyperplasia and hypertrophy of synovial lining cells are seen.The predominant infiltrating cells are $\mathrm{CD}_{4} \mathrm{~T}$ lymphocytes.Infiltration of large number of $\mathrm{B}$ lymphocytes that differentiate into plasma cells is also seen.Finally synovial fibroblasts accumulate and produce enzymes such as collagenase and cathepsin that degrade components of articular matrix. The rheumatoid synovium is characterized by the presence of a number of secretory products like $\mathrm{IL}_{2}$, $\gamma$ interferon, $\mathrm{IL}_{6}, \mathrm{IL}_{10}$. GM$\mathrm{CSF}, \mathrm{TNF}-\alpha$.There is also increased production of anaphylatoxins(C3a,C5a) in the synovium. In Rheumatoid arthritis there is malfunctioning of body's immune system and chronic inflammation within the joint which leads to destruction of joint cartilage and bone.

In approximately $2 / 3^{\text {rd }}$ of patients,rheumatoid arthritis begins insidiously with fatigue ,anorexia and generalized weakness.Pain,swelling and tenderness are observed initially at joints.Morning stiffness ${ }^{[6]}$ of joints for more than 1hour is seen.Rheumatoid arthritis most often causes symmetric arthritis, with characteristic involvement of proximal interphalangeal and metacarpophalangeal joints.Knee joints and upper cervical spine 
are commonly involved.Rheumatoid nodules develop in $20-30 \%$ of patients with rheumatoid arthritis. They are usually found in periarticular structures and extensor surfaces.In more aggressive form ,rheumatoid vasculitis ${ }^{[7]}$ causes polyneuropathy, mononeuritis multiplex,cutaneous ulceration,dermal necrosis, digital gangrene and visceral infarction ${ }^{[8]}$. Laboratory findings ${ }^{[9]}$ include presence of rheumatoid factors which are autoantibodies reacting with Fc portion of ImmunoglobulinG.Normochromic normocytic anemia,leukopenia and eosinophilia are seen in blood smear.Synovial fluid analysis shows turbid fluid with reduced viscosity,increased protein content,decreased or normal glucose levels and increased number of (>2000)polymorphonuclear leuckocytes. The diagnosis is supported by characteristic pattern of joint abnormalities including tendency towards symmetric involvement.

Juxta-articular osteopenia may become apparent within weeks of onset on imaging ${ }^{[10]}$.Loss of articular cartilage and bone erosion develop after months of sustained activity.Non-pharmacological management involves complete bed rest, relaxation and stretching exercises to prevent flexion contractures. Medical management of rheumatoid arthritis involves four general approaches. The first is use of NSAIDs, second is use of low dose glucocorticoids, third is Disease modifying antirheumatic drugs(DMARDs) and lastly use of intraarticular glucocorticoids.

NSAIDs have been used for decades for treatment of pain and inflammation.NSAIDs affect arachidonic acid Cascade by inhibiting cyclooxygenase $(\mathrm{COX})$ there by attenuating prostaglandin and thromboxane production.

COX exists as 2 isoforms.COX-1 is constitutive form and COX-2 is both inducible and constitutive forms.COX-1 is expressed in most cells throughout the body. products of COX-1are involved in regulation of platelet function, renal function,electrolyte balance and protection of gastrointestinal mucosa.COX-2 is mainly produced by inflammatory and immune cells[neutrophils,macrophages,mastcells etc.].COX-2 IS responsible for the production of prostaglandins that mediate inflammation and pain.

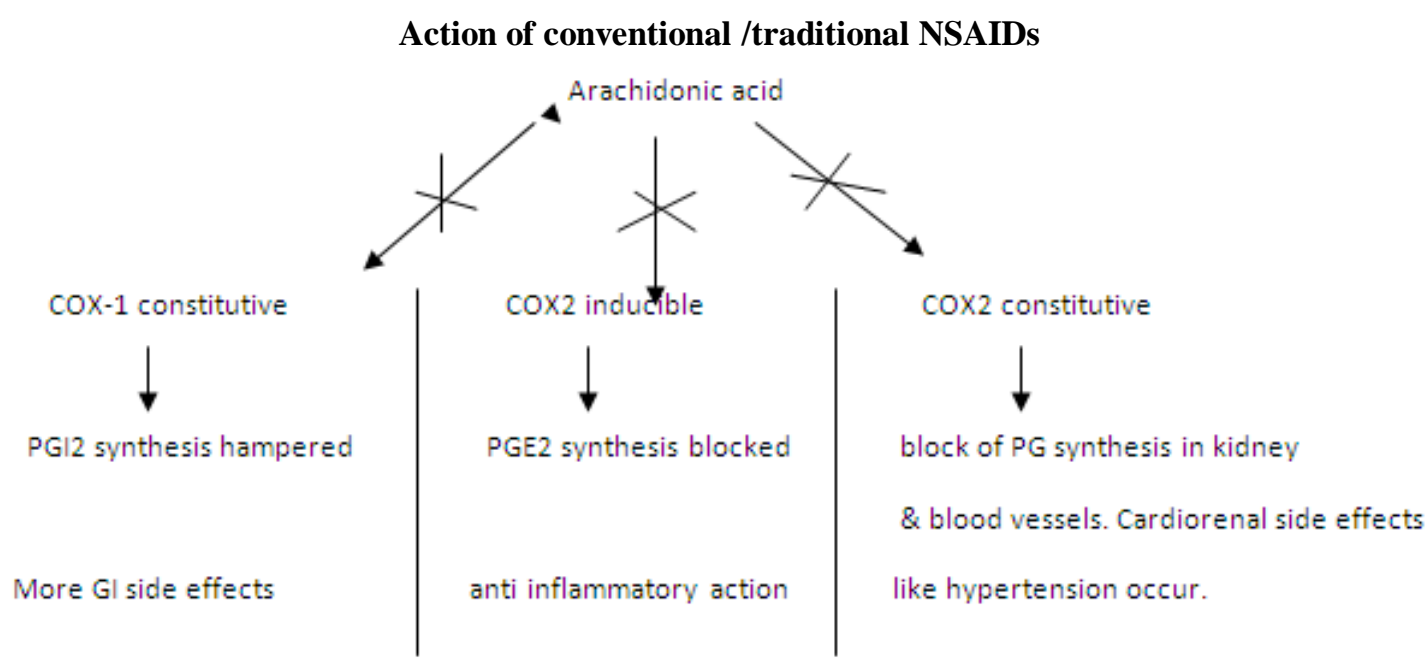

Aceclofenac ${ }^{111]}$,a phenyl acetic derivative(2-(2,6-dichlorophenyl)amino derivative), is a novel COX-2 inhibitor Indicated for treatment of pain and inflammation.It's molecular formula is $3 \mathrm{C} 16 \mathrm{H} 13 \mathrm{C} 12 \mathrm{NO} 4$ and molecular weight is 354.2 Daltons.It is a white crystalline powder with 99.2 to $101 \%$ purity and melting point is $149-153^{\circ} \mathrm{C}$.It is rapidly absorbed after oral administration and bioavailability is about $100 \%$.Peak plasma concentration is occurs after 1.25 to 3 hours after ingestion.It is highly protein bound( $>99.7 \%)$ The concentration in synovial fluid is about $60 \%$ of the plasma concentration.It is metabolized by CYP2C 9 and main metabolites are 4 hydroxy aceclofenac, diclofenac and 4hydroxy diclofenac. The mean plasma half-life is 4-4.3hrs and 2/3 rd of the drug is eliminated in urine.Aceclofenac inhibits increase of inflammatory tissue in the synovial layer.It inhibits IL-1(interleukin) and Matrix metallo protease(MMP)It ensures proteoglycan production.It blocks suppression of Gag gene and stimulates growth factor mediated synthesis of collegan. 


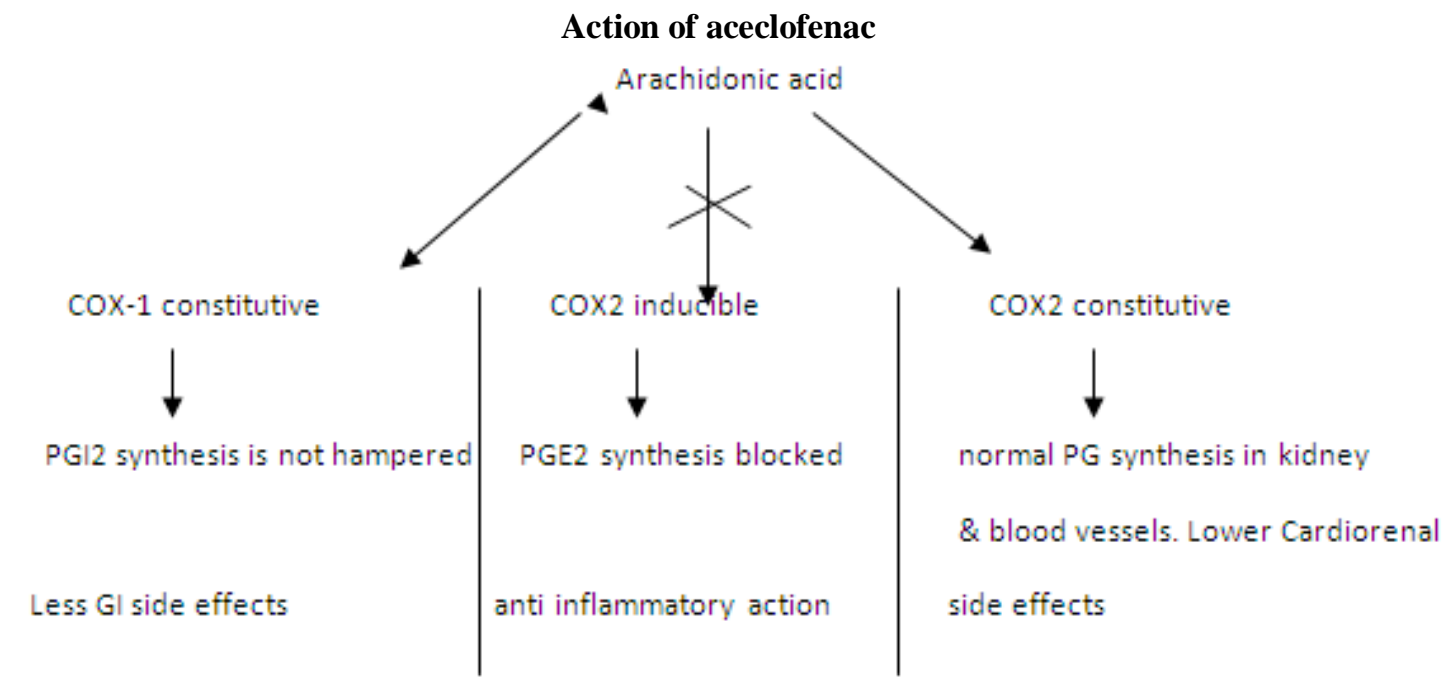

Adverse effects are mild which include epigastric pain,nausea,headache,dizziness and rashes.Doasge is $100 \mathrm{mg}$ tablet ,one in the morning and one at night orally.It can be taken before or after food. Etoricoxib ${ }^{[12]}$ is a NSAID and a selective COX inhibitor.It is chemically designated as 5-chloro 6-methyl-3(p-(methyl Sulfonyl)phenyl)2-3 bipyridine.Its empirical formula is $\mathrm{C}(18) \mathrm{H}(15) \mathrm{CIN}(2) \mathrm{O}(2)$ S.Its molecular weight is 358.8 daltons.

It also referred as MK-0663.Oral bioavailability of the drug is $100 \%$.Tmax is about $1 \mathrm{hr}$ and plasma half-life is $22 \mathrm{hrs}$.

Area under curve is about $37.8 \mathrm{mg}$ per hr.Plasma protein binding is about $92 \%$.Volume of distribution is about $120 \mathrm{~L}$. Etoricoxib ${ }^{[13]}$ is excreted in the urine primarily as metabolites. The elimination half-life is about $22 \mathrm{hrs}$.It is a potent inhibitor of COX-2 enzyme .It provides anti-inflammatory and analgesic effect by blocking COX-2 inducible form.

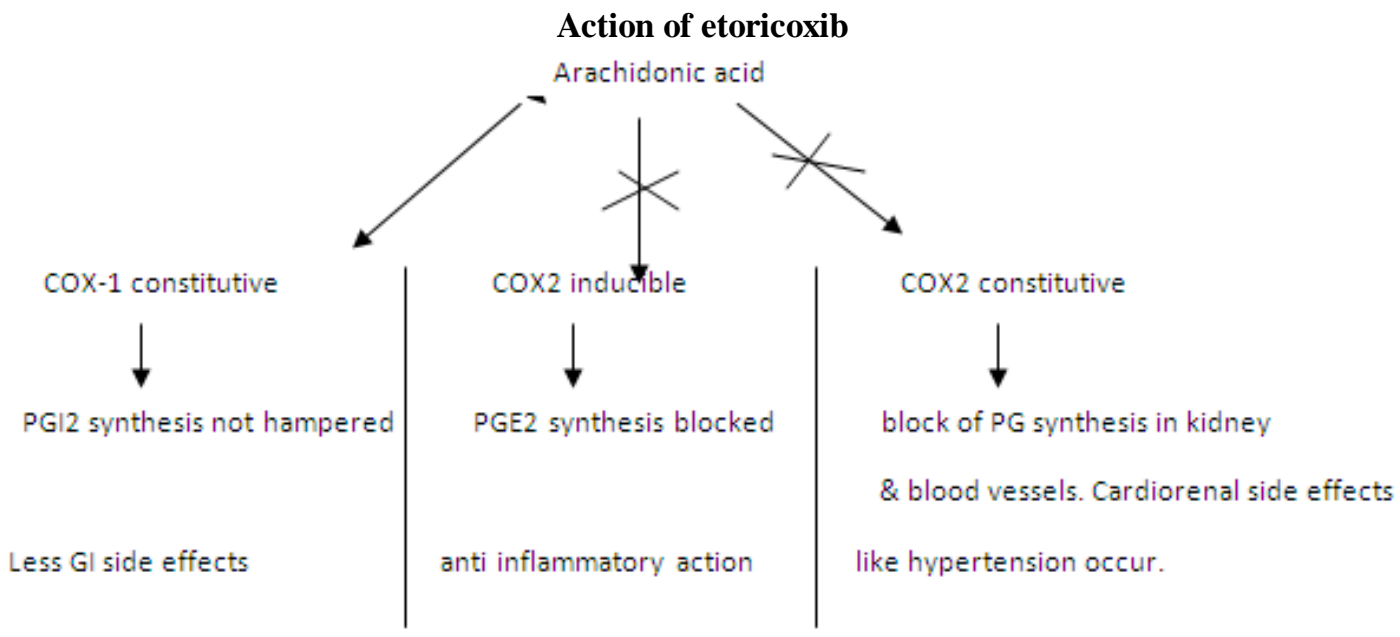

Adverse effects include dyspepsia,abdominal pain,pedal edema,rise in blood pressure and dry mouth.It is administered as $90 \mathrm{mg}$ tablet once daily orally.

\section{Materials And Methods}

A prospective,randomized parallel,open clinicaltrail was conducted on 70patients at department of pharmacology[Kurnool medical college] in collaboration with department of orthopedics, Government General Hospital.The patient population with rheumatoid arthritis were recruited by using inclusion criteria. Patients were diagnosed as rheumatoid arthritis if they have morning stiffness lasting more than one hour or more for atleast six weeks, two or more swollen joints and detection of rheumatoid factor. Both females and males with 
age group 16 to 70 years were selected..Exclusion criteria includes rheumatoid arthritis patients if history for more than two years,patients was already on DMARDs,patients with positive radiographic findings[juxtaarticular osteopenia and loss of articular cartilage] and bone erosion.Patients with renal impairment,myocardial infarction,liver failure,hypertension and diabetes mellitus were excluded.Informed consent was taken from 70 patients, 4 patients were excluded as they met exclusion criteria.Out of66patients, 33 patients were randomly given aceclofenac [HINAC 100mg tablet twice a day orally]. Other 33 patients were given etoricoxib[ COXYVEEN 90mg once daily orally]. 6 patients, 3 from each group did not attend the follow up. Thus the final sample size is 30 patients from each group.After allocating the patients to respective groups,pain at the joints was assesed through visual analogue[VAS $]^{[14]}$ and number of tender joints. The changes in the bloodpressure in systolic and diastolic were studied after administration of drugs .The incidence of peptic ulcer was investigated.To clinically asses four visits were scheduled.At the first visit were selected,at the second visit patient were allotted drugs,third visit was scheduled at 12 weeks and fouth visit was scheduled at 24 weeks.In the $\mathrm{VAS}^{[15]} 0 \mathrm{~cm}$ indicates no pain and $10 \mathrm{~cm}$ indicates unbearable pain. The decrease in the number of tender joints after 24weeks of treatment are compared.

Bloodperssures[systolic \& diastolic] were measured at all vists with mercuric sphygmomanometer.Incidence of peptic ulcer was evaluated at each visit using questionnaire.Endoscopy was done in 5 patients complaining of severe epigastric pain. $\mathrm{VAS}^{[16]}$, decrease in number of tender joints, blood pressure changes are compared in both groups using student t-test.Incidence of peptic ulcer is compared using chi square test.All statistical tests were two tailed and $\mathrm{p}$ values rounded to two decimal places.P $<0.05$ was considered statistically significant. Statistical analysis of data was performed using SPSS version 17.0.

\section{Results}

Among 60 patients satisfying the inclusion criteria,30 patients received aceclofenac and 30 received etoricoxib therapy. The mean age of patients taking aceclofenac was $44.8 \pm 2.18$ while that of patients in group 2 was $47.3 \pm 1.77$. Out of $60,25 \%$ were males and $75 \%$ were females .

Table 1. Baseline characteristics of patients receiving aceclofenac and etoricoxib

\begin{tabular}{|l|l|l|}
\hline VARIABLES, [MEAN/SEM] & \multicolumn{1}{|c|}{$\begin{array}{c}\text { GROUP A(n=30) } \\
\text { Aceclofenac }\end{array}$} & \multicolumn{1}{|c|}{$\begin{array}{c}\text { GROUP B(n=30) } \\
\text { Etoricoxib }\end{array}$} \\
\hline VISUAL ANALOGUE SCALE & $8.53 \pm 0.1$ & $8.33 \pm 0.11$ \\
\hline NUMBER OF TENDER JOINTS & $4.3 \pm 0.17$ & $4.77 \pm 0.17$ \\
\hline SYSTOLIC BLOOD PRESSURE & $114 \pm 1.11$ & $118 \pm 1.37$ \\
\hline DIASTOLIC BLOOD PRESSURE & $76 \pm 1.07$ & $78 \pm 0.92$ \\
\hline
\end{tabular}

Values are mean \pm standard error of mean, $\mathrm{p}<0.05$

After 24weeks,VAS,number of tender joints,blood pressure[systolic\&diastolic] were measured in both groups.

Table 2.Characteristics of patient variables at 24 weeks[n=30]

\begin{tabular}{|l|l|l|}
\hline VARIABLES, [MEAN/SEM] & \multicolumn{1}{|c|}{$\begin{array}{c}\text { GROUP A(n=30) } \\
\text { Aceclofenac }\end{array}$} & \multicolumn{1}{|c|}{$\begin{array}{c}\text { GROUP B(n=30) } \\
\text { Etoricoxib }\end{array}$} \\
\hline VISUAL ANALOGUE SCALE & $0.6 \pm 0.14$ & $2.03 \pm 0.13$ \\
\hline NUMBER OF TENDER JOINTS & $0.5 \pm 0.12$ & $1.83 \pm 0.15$ \\
\hline SYSTOLIC BLOOD PRESSURE & $114 \pm 1.11$ & $130 \pm 2.93$ \\
\hline DIASTOLIC BLOOD PRESSURE & $76 \pm 1.07$ & $86 \pm 1.55$ \\
\hline
\end{tabular}

Values are mean \pm standard error of mean, $\mathrm{p}<0.05$

Table 3.The mean reduction in VAS,number of tender joints in patients taking aceclofenac and etoricoxib was calculated.

\begin{tabular}{|l|c|c|}
\hline VARIABLES, [MEAN/SEM] & \multicolumn{1}{|c|}{$\begin{array}{c}\text { GROUP A(n=30) } \\
\text { Aceclofenac }\end{array}$} & $\begin{array}{r}\text { GROUP B(n=30) } \\
\text { Etoricoxib }\end{array}$ \\
\hline $\begin{array}{l}\text { MEAN REDUCTION IN } \\
\text { VISUAL ANALOGUE SCALE }\end{array}$ & $8.4 \pm 0.19$ & $6.33 \pm 0.19$ \\
\hline $\begin{array}{l}\text { MEAN REDUCTION IN NUMBER OF } \\
\text { TENDER JOINTS }\end{array}$ & $3.8 \pm 0.27$ & $2.93 \pm 0.41$ \\
\hline
\end{tabular}

Values are mean \pm standard error of mean, $\mathrm{p}<0.05$ 
Table 4. Effect of Aceclofenac and Etoricoxib on systolic blood pressure in Rheumatoid arthritis patients

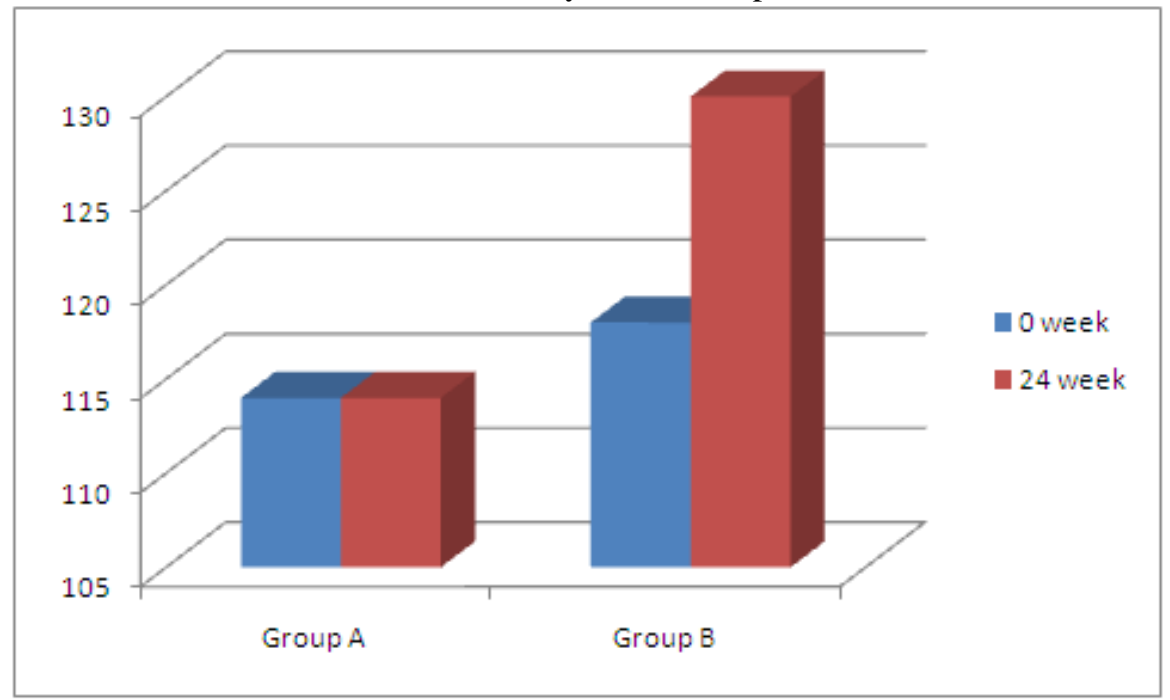

Table5. Effect of Aceclofenac and Etoricoxib on Diastolic blood pressure in Rheumatoid arthritis Etoricoxib causes increase in blood pressure[p $<0.05]$.The result is statistically significant

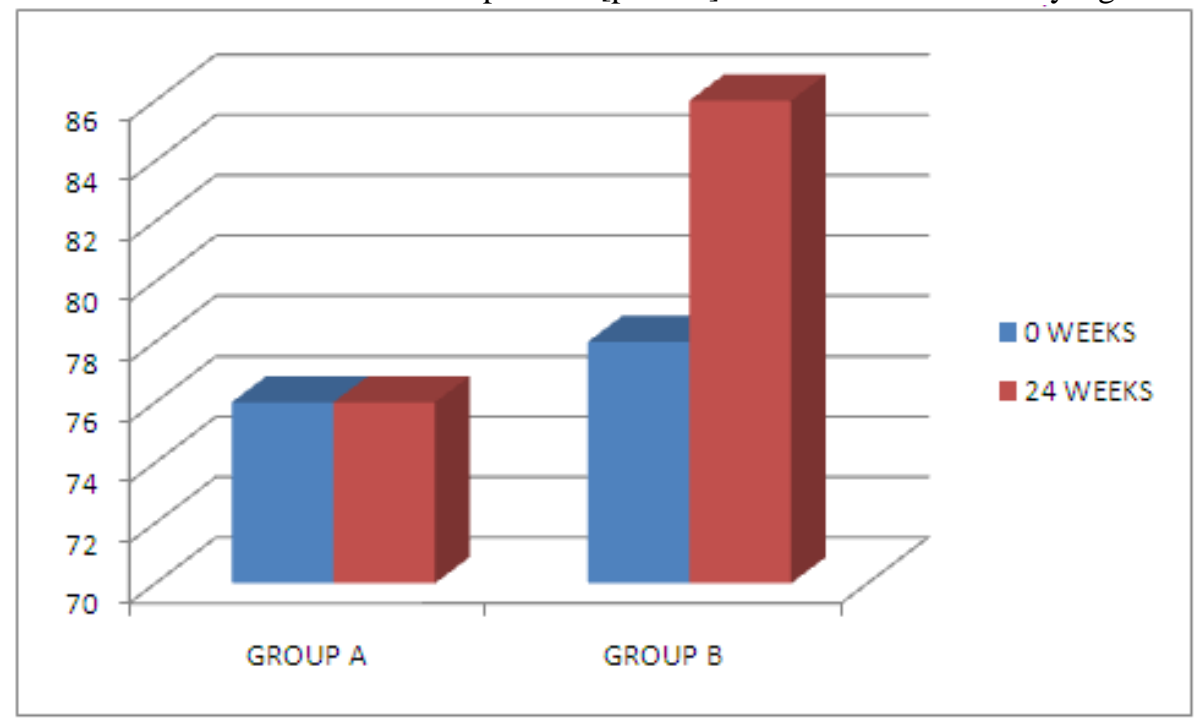

Table 6.Chi Square Chart

\begin{tabular}{|l|c|c|c|}
\hline \multicolumn{1}{|c|}{ DRUGS } & $\begin{array}{l}\text { PATIENTS WITH } \\
\text { PEPTIC ULCER }\end{array}$ & NORMAL & TOTAL \\
\hline ACECLOFENAC & 1 & 29 & 30 \\
\hline ETORICOXIB & 0 & 30 & 30 \\
\hline TOTAL & 1 & 59 & 60 \\
\hline
\end{tabular}

$\mathrm{X}^{2}=\sum(0-\mathrm{E})^{2} / \mathrm{E}=0.89$

On referring $\mathrm{x} 2$ table with one degree of freedom the value for $\mathrm{x} 2$ for a probability of 0.05 is 3.84 The observed value of 0.89 is less than 3.84. $(\mathrm{P}>0.05)$ Thus the result is not statistically significant

\section{Discussion}

NSAIDs are considered safe and effective first line medicines for analgesia in rheumatoid arthritis patients. The age of patients ranged from 16 to 70 years,out of which $80 \%$ were in age group 37 to 57 years.Out of 60 patients 45 were females and 15 were males. this study observed that aceclofenac showed greater degree of analgesia than etoricoxib.T he measuring of pain was done using VAS and counting tender joints.In VAS, score 0 ,indicates no pain,no swelling of joints and normal mobility of joints.Score $1 \mathrm{~cm}$ indicates distress, Score $2,3 \mathrm{~cm}$ indicates annoying pain,.Score $4,5 \mathrm{~cm}$ indicates uncomfortable pain,.Score 6,7 indicates dreadful pain,score 8,9 indicatehorrible pain, score 10 indicates agonizing pain. The mean decrease in VAS scale in 
group A patients was $8.4 \pm 0.19$, while in group B was $6.33 \pm 0.8$ (Table $1 \& 2$ ). The mean decrease is more for aceclofenac than etoricoxib. This decrease was statistically significant $(\mathrm{p}<0.05)$. figure 7

\section{Visual analoge scale}

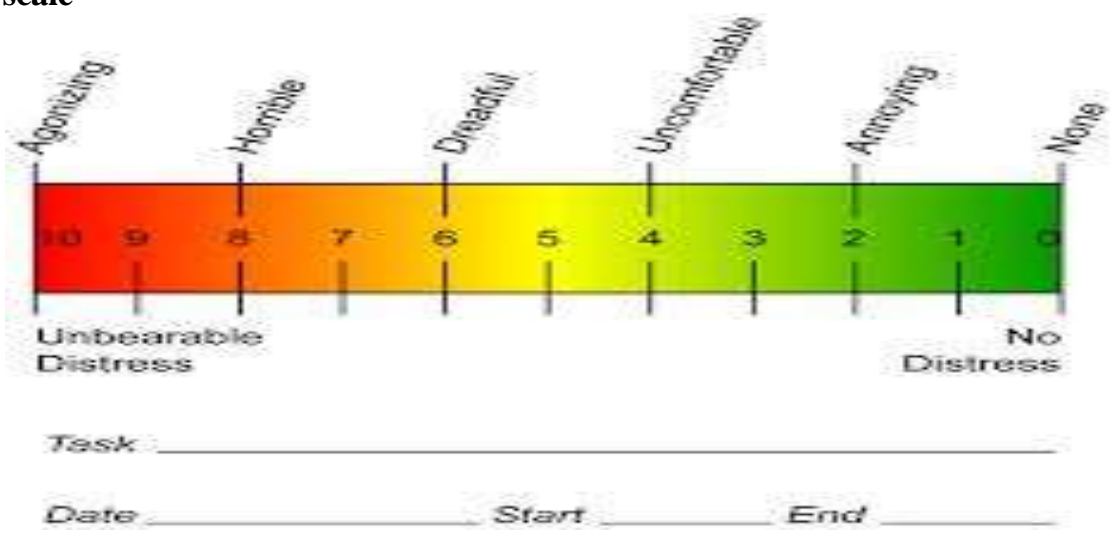

The mean decrease in tender joints in group A was $3.8 \pm 0.27$, while in group B was $2.93 \pm 0.4$ (Table $3)$. The decrease in number of tender joints was also statistically significant $(p<0.05)$. The study observed that aceclofenac has no effect on blood pressure while etoricoxib caused mild increase in blood pressure.The mean systolic blood pressurebefore taking etoricoxib was $118 \pm 1.37$ and after 24 weeks of taking etoricoxib was $130 \pm 2.93$. The mean increase in systolic blood pressure was $12 \pm 0.14 \mathrm{~mm}$ of $\mathrm{Hg}$. The mean diastolic blood pressure before taking etoricoxib $78 \pm 0.92$ and after 24 weeks was $86 \pm 1.55 \mathrm{mmHg}$. The mean increase was $8 \pm 0.16 \mathrm{~mm} \mathrm{Hg}$ (Table 1,2\&4,5). This finding was statistically significant $(\mathrm{p}<0.05)$. There was incidence of peptic ulcer in 1 patient taking aceclofenac which was statistically insignificant.(Table 6).

Recent studies have indicated that NSAIDs induce apoptosis in rheumatoid synovial cells. This is brought about by activation of peroxisome proliferator activated receptor $\gamma($ PPAR- $\gamma)$. The apoptosis of synovial cells was identified by DNA fragmentation assay and terminal deoxnucleotidal transferase mediator uridyl triphosphate nick and labeling assay. Aceclofenac and etoricoxib reduce cell proliferation and induce apoptotic cell death in synovial cells. This causes decrease in viability of inflammatory cells in joint cavity.Traditional NSAIDs inhibit both COX-1 and COX-2 thus causing gastrointestinal side effects. Aceclofenac inhibits COX$2^{[17]}$ inducible enzyme and is with less GI sideeffects and hypertension. Etoricoxib inhibits COX-2 inducible and constitutive enzymes causing cardio renal side effects and hypertension.DMARDs ${ }^{[18]}$ for rheumatoid arthritis include gold compounds, D-penicilamine, chloroquine, sulfasalazine ,methotrexate, azathioprine and cyclophosphomide.Methotrexate is the commonly used third line drug for rheumatoid arhthritis patients where as low dose corticosteroid ${ }^{[19]}$ are second line of treatment.The newer drugs for rheumatoid arthritis are biological response modifiers ${ }^{[20]}$ which includes etanercept, adalimumab, anakinra and infliximab.

\section{Conclusion}

Comparaitive study of aceclofenac and etoricoxib on degree of analgesia and assessment of incidence of hypertension and peptic ulcer in rheumatoid arthritis was done. The study concludes that aceclofenac is a better analgesic than etoricoxib.Etoricoxib caused mild hypertension which is statistically significant..

\section{Acknowledgement}

We thank head of the department of pharmacology and department of orthopaedics ,Government general hospital Kurnool.

\section{References}

[1]. Goeldner I, Skare TL, de Messias Reason IT, Nisihara RM, Silva MB, Utiyama SR (Aug 2010). "Anti-cyclic citrullinated peptide antibodies and rheumatoid factor in rheumatoid arthritis patients and relatives from Brazil". Rheumatology (Oxford) 49 (8): 15903.doi:10.1093/rheumatology/keq134. PMID 20457731.

[2]. Edwards JC, Cambridge G, Abrahams VM (1999). "Do self-perpetuating B lymphocytes drive human autoimmune disease?". Immunology 97 (2): 188-96. doi:10.1046/j.1365-2567.1999.00772.x. PMC 2326840.PMID 10447731.

[3]. Doherty, M; Lanyon, P; Ralston, SH. Musculosketal Disorders-Davidson's Principle of Internal Medicine (20th ed.). Elsevier. pp. $1100-1106$.

[4]. Plenge RM, Seielstad M, Padyukov L, Lee AT, Remmers EF, Ding B, Liew A, Khalili H, Chandrasekaran A, Davies LR, Li W, Tan AK, Bonnard C, Ong RT, Thalamuthu A, Pettersson S, Liu C, Tian C, Chen WV, Carulli JP, Beckman EM, Altshuler D, Alfredsson L, Criswell LA, Amos CI, Seldin MF, Kastner DL, Klareskog L, Gregersen PK (2007). "TRAF1-C5 as a Risk Locus for Rheumatoid Arthritis - A Genomewide Study". N. Engl. J. Med. 357 (12): 1199209. doi: $10.1056 /$ NEJMoa073491. PMC 2636867.PMID $\underline{\text { 17804836. }}$ 
[5]. Robbins, Stanley Leonard; Kumar, Vinay; Abbas, Abdul K.; Cotran, Ramzi S.; Fausto, Nelson (2010). Vinay Kumar, Abul K. Abbas, Nelson Fausto, ed. Robbins and Cotran pathologic basis of disease. Robbins Pathology Series (Elsevier). p. 205. ISBN $\underline{978-}$ 1-4160-3121-5.

[6]. Majithia V, Geraci SA (2007). "Rheumatoid arthritis: diagnosis and management". Am. J. Med. 120 (11): 9369.doi:10.1016/j.amjmed.2007.04.005. PMID 17976416.

[7]. Shah, Ankur. Harrison's Principle of Internal Medicine (18th ed.). United States: McGraw Hill. p. 2749. ISBN 978-0-07174889-6.

[8]. Davidson's principles and practice of medicine. (21st ed.). Edinburgh: Churchill Livingstone/Elsevier. 2010. ISBN 978-0-70203084-0.

[9]. Westwood OM, Nelson PN, Hay FC (2006). "Rheumatoid factors: what's new?". Rheumatology (Oxford) 45 (4): 37985.doi:10.1093/rheumatology/kei228. PMID 16418203.

[10]. Shah, Ankur. Harrison's Principle of Internal Medicine(18th ed.). United States: McGraw Hill. p. 2738. ISBN 978-0-07174889-6

[11]. http://drugsynthesis.blogspot.co.uk/2012/03/synthesis-of-aceclofenac.html

[12]. Bombardier, Claire; Laine, Loren; Reicin, Alise; Shapiro, Deborah; Burgos-Vargas, Ruben; Davis, Barry; Day, Richard; Ferraz, Marcos Bosi; Hawkey, Christopher J.; Hochberg, Marc C.; Kvien, Tore K.; Schnitzer, Thomas J. (2000). "Comparison of Upper Gastrointestinal Toxicity of Rofecoxib and Naproxen in Patients with Rheumatoid Arthritis". New England Journal of Medicine 343 (21): 1520. doi: 10.1056/NEJM200011233432103. PMID 11087881.

[13]. Cannon, Christopher P; Curtis, Sean P; Fitzgerald, Garret A; Krum, Henry; Kaur, Amarjot; Bolognese, James A; Reicin, Alise S; Bombardier, Claire; Weinblatt, Michael E; Van Der Heijde, Désirée; Erdmann, Erland; Laine, Loren (2006). "Cardiovascular outcomes with etoricoxib and diclofenac in patients with osteoarthritis and rheumatoid arthritis in the Multinational Etoricoxib and Diclofenac Arthritis Long-term (MEDAL) programme: A randomised comparison". The Lancet 368 (9549): 1771. doi:10.1016/S0140-6736(06)69666-9.

[14]. U.-D. Reips and F. Funke (2008) "Interval level measurement with visual analogue scales in Internet-based research: VAS Generator."doi:10.3758/BRM.40.3.699

[15]. S. Grant, T. Aitchison, E. Henderson, J. Christie, S. Zare, J. McMurray, and H. Dargie (1999) A comparison of the reproducibi lity and the sensitivity to change of visual analogue scales, Borg scales, and Likert scales in normal subjects during submaximal exercise. Chest. 116(5):1208-17. doi: $10.1378 /$ chest.116.5.1208

[16]. Funke, F; Reips, U.-D. (2012). "Why semantic differentials in Web-based research should be made from visual analogue scales and not from 5-point scales." (PDF). Field Methods 24: 310-327. doi:10.1177/1525822X12444061

[17]. The FDA concluded its revision on April 6, 2005: the final document can be found here. The EMA concluded its revision on June 27, 2005: the final document can be found here

[18]. Scott DL, Wolfe F, Huizinga TW (Sep 25, 2010). "Rheumatoid arthritis". Lancet 376 (9746): 1094-108.doi:10.1016/S01406736(10)60826-4. PMID 20870100

[19]. Per-Olof Hasselgren, Nima Alamdari, Zaira Aversa, Patricia Gonnella, Ira J Smith, and Steven Tizio. CORTICOSTEROIDS AND MUSCLE WASTING ROLE OF TRANSCRIPTION FACTORS, NUCLEAR COFACTORS, AND HYPERACETYLATION. Curr Opin Clin Nutr Metab Care. 2010 July; 13(4): 423-428. URL:http://ncbi.nlm.nih.gov/pmc/PMC2911625

[20]. $\quad$ "Biological Response Modifiers (BRM)" 